\title{
The Triple Helix after communism: Russia and China compared
}

\author{
Harley Balzer ${ }^{1^{*}}$ (D) and Jon Askonas ${ }^{2}$
}

\author{
* Correspondence: \\ balzerh@georgetown.edu \\ 'Department of Government, ICC \\ 681, Georgetown University, \\ Washington, DC 20057, USA \\ Full list of author information is \\ available at the end of the article
}

\begin{abstract}
Russia and China both are endeavoring to transform Soviet-style R\&D systems characterized by separate education, research and business spheres into something more suited to a knowledge economy supporting innovation. The Triple Helix model is an attractive configuration, derived from the practices of the most successful innovation systems, and suggesting that the three key actors-universities, business, and the state-might in some instances substitute for each other. A model placing the state at the center appeals to non-democratic regimes and countries endeavoring to catch up with OECD nations.

We compare the Chinese and Russian efforts to implement a Triple Helix program by examining institutional change, epistemic communities, funding, and the role of the state, with nanotechnology as a case study. While both nations have introduced major programs and allocated significant funding, we find that China has been vastly more successful than Russia in promoting collaboration among universities, business, and government to advance research and innovation. We attribute the difference to the quality of state policies that provide incentives for agents and epistemic communities to alter their behavior, an outcome facilitated by conditions at the beginning of reforms, which made the Chinese far more open to learning.
\end{abstract}

Keywords: Post-Soviet science, Triple Helix, Chinese science, Russian science, Science policy, Innovation

\section{Resumen}

Rusia y China buscan transformar los sistemas de $1 \& D$ de la era soviética. Desean ir de un sistema caracterizado por educación, investigación y empresa en esferas separadas hacia un sistema mejor integrado y más apto para la economía del conocimiento. El modelo de la Triple Hélice permite un rol más flexible para los actores de innovación—universidades, empresas, y el Estado—donde bajo ciertas circunstancias, un actor puede sustituir a otro en algunas funciones. Ese es un modelo atractivo para países que se esfuerzan por alcanzar a las naciones de la OECD, y en particular para regímenes políticos que desean un rol más central para el estado. Comparamos los esfuerzos de China y Rusia con un estudio de caso: el desarrollo de la nanotecnología. Examinamos cambios institucionales, comunidades epistémicas, financiamiento de investigación, y el papel del Estado. Mientras que ambas naciones han introducido programas de promoción para la innovación y han asignado fondos importantes para esos proyectos, China ha sido mucho más exitosa que Rusia en la promoción de la colaboración entre universidades, empresas y el (Continued on next page)

\section{Springer}

(C) 2016 Balzer and Askonas. Open Access This article is distributed under the terms of the Creative Commons Attribution 4.0 international License (http://creativecommons.org/licenses/by/4.0/), which permits unrestricted use, distribution, and reproduction in any medium, provided you give appropriate credit to the original author(s) and the source, provide a link to the Creative Commons license, and indicate if changes were made. 
(Continued from previous page)

gobierno. Atribuimos la diferencia a políticas de incentivos (tanto para agentes individuales como para comunidades epistémicas) que han modificado el comportamiento de los actores de innovación y han permitido a las organizaciones Chinas adaptarse y aprender mejor de su experiencia.

\section{Résumé}

La Russie et la Chine se sont engagées à transformer des systèmes de recherche de type soviétique caractérisés par la séparation des sphères des affaires, de l'éducation et de la recherche en quelque chose de plus convenable à une économie du savoir base de l'innovation. Le modèle de la Triple Hélice est une configuration attrayante dérivée des pratiques des systèmes d'innovation à succès ; il suggère que les trois acteurs clés -université, entreprise et pouvoirs publics- doivent se substituer l'un à l'autre dans certaines mesures. Un modèle qui place l'Etat au centre rappelle des régimes non démocratiques et des pays en retard par rapport aux nations membres de l'OCDE. Nous comparons les efforts de la Chine et de la Russie à mettre en œuvre le programme de la Triple Hélice en examinant les changements institutionnels, les communautés épistémiques, le financement et le rôle de l'Etat, le domaine de la nanotechnologie servant d'étude de cas. Les deux pays ont introduit des réformes majeures et alloué significativement des fonds; cependant la Chine a largement mieux réussi que la Russie à promouvoir la collaboration entre université, entreprise et pouvoirs publics pour faire avancer la recherche et l'innovation. La différence est due à la qualité des politiques publiques qui incitent les agents et communautés épistémiques à changer de comportement. Ce résultat est favorisé par les conditions initiales des réformes qui font de la Chine un pays de loin ouvert à l'apprentissage.

\section{摘 要}

俄罗斯和中国都在努力从以教育、科研和商业领域彼此独立为特征的苏维埃式 R\&D体系向更适合于支持创新的知识经济体系转变。三螺旋模式是个有吸引力 的配置,它来自对最成功的创新体系实践的观察，主张三个创新主体一高校、产业 和政府 - 在某些情况下可以(在功能上)相互替代。一个将国家置于中心地位的模 式对应着非民主政体和正在努力赶上经合组织国家的国家。通过考察制度变 革、认知共同体、资金和国家(政府)的作用,并以纳米技术作为案例研究,我们比 较了中国和俄罗斯在实现三螺旋项目方面的努力。我们发现,虽然这两个国家都 已经引进主要项目、分配重大资金,但在促进高校、企业和政府之间合作进行研 发和创新方面，中国已经取得更大得多的成功，远远超过了俄罗斯。我们将差异归 处于国家政策的质量，这些政策为中介机构和认知共同体提供激励改变自己的行 为，它们是在改革之初由环境促成的结果，使中国更加开放去学习(先进的东西)。

\section{Аннотация}

Россия и Китай прикладывают значительные усилия для того, чтобы привести научно-исследовательские системы советского типа, для которых характерно разделение сфер образования, исследований и бизнеса, к инновационноориентированным экономическим системам, основанным на знаниях. В данном контексте модель Тройной спирали является привлекательной, поскольку в ней аккумулирован опыт наиболее успешных инновационных систем: она основывается на трех ключевых акторах - университеты, бизнес и государство, которые в ряде случаях могут замещать друг друга. Вариант модели, где власти отводится ведущая (Continued on next page) 
(Continued from previous page)

роль, обычно базируется на недемократических принципах; такие экономические системы стремятся приблизиться в своем развитии к странам OECD (Организация экономического сотрудничества и развития).

Мы сравнили инициативы России и Китая, предпринимаемые в области внедрения принципов Тройной спирали, исследовав изменения в институциональной сфере, финансировании и степени вовлеченности государства, на примере нанотехнологий. Несмотря на то, что в обеих странах в данной сфере реализуются стратегические программы и выделяются значительные средства, мы обнаружили, что Китай более успешен, чем Россия в контексте укрепления сотрудничества между университетами, бизнесом и правительством в вопросах поддержки научных исследований и инноваций. Мы связываем это различие с качеством правительственных стратегий, которые стимулируют участников и их объединения к смене модели поведения на начальном этапе реализации реформ, благодаря чему Китай является более открытым к новым знаниям.

\section{Resumo}

Russia e China estão ambos se esforçando para transformar seus sistemas P\&D de estilo soviético, caracterizado pela separação das esferas de educação, pesquisa e empresa, em algo mais adequado para economia do conhecimento que apóie a inovação. O modelo de Hélice Tríplice é uma configuração atrativa derivado das práticas de sistemas de inovação mais bem-sucedidos, e sugere que os três atores chave - universidades, empresa e governo- podem em alguns casos, substituir um ao outro. O modelo que coloca o papel central no governo é observado em regimes não democráticos e países que se esforçam para recuperar o atraso em relação às nações da OCDE. Nós comparamos os esforços russos e chineses para implementar um programa baseado na Hélice Tríplice, examinando a mudança institucional, as comunidades epistêmicas, o financiamento e o papel do governo, tendo a nanotecnologia como estudo de caso. Embora ambas as nações tenham introduzido grandes programas e alocado recursos financeiros significativos, nós verificamos que a China tem tido muito mais sucesso do que a Rússia em promover a colaboração entre universidades, empresas e governo para avançar a pesquisa e a inovação. Nós atribuímos esta diferença à qualidade das políticas de estado que fornecem os incentivos aos agentes e comunidades epistêmicas para alterar seus comportamentos, um resultado facilitado pelas condições no início das reformas, o que fez os Chineses muito mais abertos ao aprendizado.

\section{Multilingual abstract}

Please see Additional file 1 for translation of the abstract into Arabic.

Nations aspiring to great power status in the twenty-first century share the goal of developing knowledge economies capable of innovation to undergird prosperity and modern military capabilities. The Soviet model of state financing for separate higher education, basic research, and industrial research institutions failed in this competition. Nearly all former communist nations now are endeavoring to reform their education and research systems, with some new EU members and several Asian countries doing moderately well. The CIS nations are having more difficulty. China and Russia, the two largest post-communist economies and the two countries aspiring to great power status, provide stark contrasts in their success adapting the Soviet model to twenty-first- 
century competition. The comparison is of particular interest because China adopted the Soviet system with significant assistance from the USSR in the 1950s (Bernstein and Li 2010).

To state the difference bluntly, China is achieving more than anyone dreamed possible when Deng Xiaoping first announced reform and openness, while Russia is failing in ways few anticipated. Following economic, educational, and scientific reforms in the 1980 s and 1990s, China has emerged in the 2000s as a world leader in scientific publications and patenting and is poised to compete in innovation (Balzer 2010; 2014; Strategy\& 2014; Huang and Sharif 2015; McKinsey 2015). Russia has steadily declined in global higher education rankings, scientific influence, and innovation (Kotsemir 2012; Balzer 2010). Why has China been more successful in reforming the Soviet model? Our solution to this puzzle emphasizes China's thick compared to Russia's thin international integration, stemming from the interaction of epistemic communities, economic interests, and state agents since the start of reform efforts.

The complex synergy among business, the state, and higher education institutions to produce innovation has been discussed since the 1950s. In the past two decades, the relationship has been codified in the "Triple Helix" model. The Triple Helix literature describes innovation through two explanatory frameworks encompassing the government, academia, and business. Etzkowitz and Leydesdorff's (2000) Triple Helix model links institutional and evolutionary explanations of innovation, the former focusing on the configuration of university, industry, and government networks, the latter emphasizing selection preferences.

The institutional explanation emphasizes networks creating converging discourses that promote both information sharing and the alignment of research agendas among the three institutional actors. Etzkowitz and Leydesdorff hypothesize multiple potential institutional configurations reflecting a variety of political-economic structures, ranging from a fluid laissez-faire system to a Soviet-style state science system. The network of institutional relations, along with the resources allocated and the creative environment, determines a nation's potential for innovation, extending from basic research through the commercialization chain. Institutional arrangements are analyzed both horizontally at various different scales (local, regional, national, global) and vertically across those scales.

Where the institutional model emphasizes relations and networks, the evolutionary model highlights three different functions related to innovation: wealth creation, knowledge production, and normative control. These processes, while having natural "homes" in business, academia, and government, respectively, may be replicated or substituted by the other spheres. In this model, innovation "evolves" through the selection preferences of agents: those focused on wealth creation select for innovations that promise a profit, actors focused on knowledge select for innovations that advance science, while actors focused on control select for innovations in line with the norms they seek to advance. ${ }^{1}$

In both China and Russia, analysts have embraced the Triple Helix, frequently focusing on the potential for the state to facilitate or even foster the creative process (Zhou and Leydesdorff 2006, Leydesdorff et al. 2015, Klochikhin 2012). This discussion sometimes downplays the crucial distinction between "facilitating" and "fostering." A state capable of promoting innovation will also have the capacity to inhibit innovation, either through bad policy or predatory behavior by agents. 
What determines when state policy successfully stimulates rather than deters innovation? China and Russia present striking contrasts in their relative success in reforming institutions and creating incentives that facilitate innovation economies. Despite beginning from very similar innovation systems, China is developing institutional capacity and incentives that encourage the learning needed to compete in global technology development; Russia is dissipating its inherited science-technology capacity and becoming increasingly less competitive.

We begin with a discussion of the Triple Helix model in transition economies, noting important varieties of state behavior. We then elucidate the China-Russia difference in facilitating a triple helix model by focusing on the astonishing reversal in their standing in the global knowledge economy. We attribute the outcomes to differences in institutional adaptation, the behavior of epistemic communities, the nature of funding, and the role of the state. We illustrate the different outcomes by comparing results in the priority field of nanotechnology. Our conclusion emphasizes China's greater flexibility, learning, and internationalization.

\section{The Triple Helix model in transition economies}

An energizing optimism in the Triple Helix model, especially for developing nations, derives from offering a short-cut to catching up with more developed nations. In some instances, a degree of catch-up has been achieved (Dallago and Guglielmetti 2011; Bohle and Greskovits 2012). But, creating a competitive Triple Helix infrastructure is a protracted and expensive process, and, in many cases, deriving significant benefits from participating in the global knowledge economy has proved elusive.

China and Russia are by far the largest former communist countries, and each can cite significant scientific achievements in their past. Both adopted the Soviet system based on research conducted by academies of science and industrial research institutes, with universities relegated overwhelmingly to teaching (Graham and Dezhina 2008; Balzer 1993; Gustafson 1980). While neither has fully reformed its system, China has accomplished significantly more.

The experience of former Communist countries endeavoring to parlay a vaunted but deeply troubled science and education system into a twenty-first-century innovation economy not only highlights some of the most serious limitations of Soviet-style systems, but also offers insights regarding the Triple Helix model itself. In particular, these cases help us to refine discussions of the role of the state.

Etzkowitz (2008: 59) introduces "the optimum role of government" by stating:

A common triple helix model of innovation is emerging in societies that previously held opposing conceptions of the appropriate role of government. In "high-state" societies, where triple helix relationships have traditionally been directed top-down, bottom-up initiatives appear in conjunction with the emergence of regions, and the growth of civil society. In "low-state" societies with a laissez-faire tradition, the emergence of the triple helix is associated with a strengthening of the role of the state, acting together with university and industry, in shaping innovation initiatives.

Etzkowitz is certainly correct that "the transition from industrial to post-industrial society has encouraged a shift in the role of government in both directions." However, 
the results have varied tremendously. In Russia, productive "bottom-up initiatives" tied to the "emergence of regions" and "growth of civil society" have been conspicuously absent. Following the supposed "chaos" of the 1990s, Russia's government has emphasized control. Bottom-up initiatives are viewed with skepticism, regions are rewarded on the basis of political loyalty rather than being given incentives to foster initiative, and civil society groups receive funding based on political criteria rather than creative contributions (Balzer 2008; Rochlitz et al. 2015). The incentive structure encourages local officials to be predatory more often than developmental. The contrast with China in this regard is striking. ${ }^{2}$

Much of the Triple Helix literature assumes that governments genuinely want to encourage economic modernization, with a key role in the global knowledge economy being a major development priority. For those who respect and approve of the model, wanting to be part of this global development project appears an obvious goal. The assumption that governments and individual actors, especially regional officials and epistemic communities, uniformly share the desire to reshape institutions to achieve Triple Helix benefits plays down instances of resistance on the part of government officials, scientific institutions, and epistemic communities.

The post-communist cases provide a unique realm for examining the inevitable contention as states develop policies to engage the knowledge economy. Rather than lifting all boats, the process produces winners and losers. Communist states had similar institutional systems, and most saw themselves as full participants in the "scientific-technical revolution." The similar institutional starting points and ethos of technocracy bequeathed by the Soviet model help sharpen our perspective on the role of the state in successful innovation systems. Moreover, we can observe the degree of success in the difficult transition from state-dominated to a more balanced institutional framework.

A burgeoning literature on twenty-first-century innovation emphasizes the crucial importance of the state (Mazzucato 2013; Breznitz 2007; Block 2011; Breznitz and Murphree 2012). Yet, achieving a creative balance in formerly high-state environments involves more than just reducing the state's role. The optimal outcome is to find ways for the state to be both playing field and participant. Sometimes the state may take the lead, substituting for industry or academia (Etzkowitz 2008). But, taking the lead is not the same thing as taking over. The communist experience demonstrated that state-run economies are not particularly effective at fostering innovation. Authoritarian regimes may achieve some priorities (weapons, space launches), but they more often stifle creativity (Balzer 1989; Gaddy 1996; Bychkova et al. 2015).

Rather than a strong state, the Triple Helix system requires an effective state. Etzkowitz (2008: 82) emphasizes that successful Triple Helix synergies depend on "political organizations, industrial entities, and academic institutions that work together to improve the local conditions for innovation [emphasis added]." He suggests that "if one element is missing, or constrained from participating, another may take its part." The local or regional level is the key government player. While some city-states and small countries might be able to have broad "national innovation systems," large nations with complex economies fare better when they allow considerable local and regional discretion. China, whether intentionally or not, has achieved this far more successfully than Russia (Balzer 2008). 
It is equally crucial for government to be able to learn and adapt. In discussing "necessary and sufficient conditions" for a Triple Helix system, Etzkowitz (2008: 87) notes that success requires not just creating hi-tech firms, "but the ability, over the longer term, to generate additional clusters as earlier successes are superseded." The Boston area accomplished this when it shifted from computers to biotechnology (Etzkowitz 2008: 87-88). Here, the entrepreneurial university helped a region to "transcend a particular technological paradigm and renew itself through new technologies and firms generated from its academic base" (Etzkowitz 2008: 88). The Triple Helix means "the interaction of institutional spheres will induce nonlinearity, crossover, and coevolution" (Etzkowitz 2008:104). Flexibility that permits shifting roles over time is one major element of success.

Breznitz's (2007) discussion of Ireland, Israel, and Taiwan illustrates a range of state policies that facilitate innovation. None is perfect; each works reasonably well in its environment. In each of the three cases, the key is not that the state is able to create the "best" policy, but that it helps to facilitate an environment conducive to successful innovation. This conclusion parallels Segal's (2003:15) analysis of Chinese regional government approaches to the IT industry. Segal invokes the importance of a "good mother-in-law": a local government that on-balance is more nurturing than obstructive, and limits predation. Individual agents of any government are likely to adopt varied approaches. Some individuals may behave differently when dealing with different interlocutors, at different times, and in different situations. Whether they know the people involved, the size of the financial inducements offered, prevailing "atmosphere" (in particular government enforcement of anti-corruption laws and intermittent campaigns), and overall calculations of risk and reward in any particular transaction will influence individuals' behavior. Family finances, extended kinship, and other networks may also play a role. No government, local, regional, or national, is likely to be entirely clean or completely corrupt. Yet, we can begin to determine when the preponderance is relatively more developmental compared to environments that are more obstructionist or more predatory.

At all levels, the potential for government to substitute successfully for industry or academia assumes a government that is more developmental than predatory, along with epistemic communities that learn to recognize the benefits of international collaboration and competition. These are not either/or distinctions. Local officials might promote development for a variety of reasons, ranging from altruism or a sense of social responsibility to career advancement or venality. Different projects may involve different combinations of motives. In democracies, elected officials are accountable to voters. In non-democratic systems, the crucial factor is an incentive structure that encourages local officials to foster development and limit predation.

Russian scholars Irina Dezhina and Viktoria Kiseleva (2008) produced an impressively thorough analysis of the Triple Helix model, focusing on the experience of other countries. In their conclusion, they provide a compilation of the lessons and "best practices" for a successful innovation system that might be applied in Russia. Yet the drawback to combining all the best practices is known to any systems engineer: systems involve trade-offs, and trying to optimize every aspect of a system at once may produce disaster. While engineers constantly endeavor to improve every component, they must always work with a set of priorities regarding what to 
optimize. This suggests that a generic approach to "optimizing innovation" will not do as well as a targeted effort to identify the "best practices" that accord with a country's comparative advantage. Even best practices "with national characteristics" may not be adequate. Bychkova et al. (2015) note that Russian policies mandating that industry collaborate with academia to foster innovation have largely failed.

Russia's performance compared with China's demonstrates an astonishing reversal across a broad spectrum of knowledge economy indicators.

In the first decade of the twenty-first century, Russia dropped from 9th to 15th place in its share of the world's peer-reviewed science publications (Table 1).

During this same period, China climbed from sixth to second place in its share of world publications, with a $13.62 \%$ share (Kotsemir 2012). China's growth from 44,575 to 184,029 publications represented a more than fourfold increase. ${ }^{3}$

Russia's decline is particularly notable in fields that were areas of Soviet strength, including physics, mathematics, engineering, and space science. Failure to publish more in the key fields of twenty-first-century science, including medical science, biology, and computer science (the one exception here being software), suggests a lack of integration in emerging specialties. Russia's decline from an already low base in social science is equally striking. Table 2 provides a comparison of Russian and Chinese performance by field prior to the 2008 economic crisis. China gained in fields where Russia/USSR performed well like physics and mathematics, and also in medicine, the life sciences, and chemistry. Russian performance compares poorly with the other BRIC countries (Fig. 1)

Not only is the Russian share of global publications declining (Table 3), but Russian papers are now less likely to be cited. The global average of citations per publication is 10.57. Russia has an average citation per paper of 4.87 . Nearly half (48.6 \%) of highly cited Russian papers are in physics.

Chinese publications also are cited less often than those by scientists from developed countries. Unlike Russia, however, China's trajectory has been an increasing number of citations per paper, in part because Chinese scholars publish more in the most dynamic fields of twenty-first-century science. While both the Chinese and Russian governments have made increased global publications a significant priority, institutional weakness and "brain drain" have made this difficult for Russia, while China's openness to partnerships and some reversal of brain drain have aided a global rise in Chinese publications. Chinese scientists now contribute more to collaborative projects with scientists from all nations except the USA and Germany (P.T 2015).

As will be discussed below, China not only spends more on science and technology, but derives the funds from more diverse sources. Diverse funding and greater local discretion have helped propel China ahead of Russia on a range of the indicators tracked by the World Economic Forum. While a continuation of China's impressive ascent compared to Russia's decline is not inevitable, the trajectory of the two nations in categories like "innovation capacity," and government purchasing promoting advanced technology innovation, suggests a long-term condition (See Table 4).

Table 1 Articles published by Russian scholars in Web of Science and Essential Science Indicators, 2001 and 2011

$\begin{array}{ll}2001 & 28,665 \text { articles }=2.97 \% \text { share of world publications } \\ 2011 & 28,573 \text { articles }=2.06 \% \text { share of world publications }\end{array}$


Table 2 Chinese and Russian publications by major fields of science, 2002 and 2008

\begin{tabular}{llllll}
\hline & \multicolumn{2}{l}{ China } & & \multicolumn{2}{l}{ Russia } \\
\cline { 2 - 3 } & 2002 & 2008 & & 2002 & 2008 \\
\hline TOTAL & 38,206 & 104,968 & & 25,493 & 27,083 \\
Biology & 1716 & 5672 & & 1050 & 1317 \\
Biomedical research & 2682 & 9098 & & 1851 & 1835 \\
Chemistry & 9499 & 23,032 & & 5240 & 5308 \\
Clinical medicine & 3,863 & 13,595 & & 1599 & 1914 \\
Earth and space & 2036 & 5746 & & 2468 & 2981 \\
Engineering and technology & 8734 & 22,800 & & 3144 & 3329 \\
Mathematics & 1850 & 5384 & & 1251 & 1584 \\
Physics & 7826 & 19,641 & 8890 & 8815 \\
\hline
\end{tabular}

UNESCO Science Report 2010, pp. 508-509 and 504-505

These data suggest that China's government, if not always developmental, has been remarkably pragmatic. A significant share of Chinese officials have evinced willingness to learn from both foreign models and successful local policy innovations. This has been encouraged by an incentive structure rewarding economic success and by support from the beneficiaries of reform and members of epistemic communities who embrace international standards of professional behavior (Zweig 2002; Howell 1993; Pei 1994). The contrast with Russia is striking and is clearly visible in the speed of institutional change.

\section{Institutional change}

Despite the inevitable difficulties in a single-party regime that persists in calling itself "communist," China has made substantial progress in modifying its Soviet-style system.

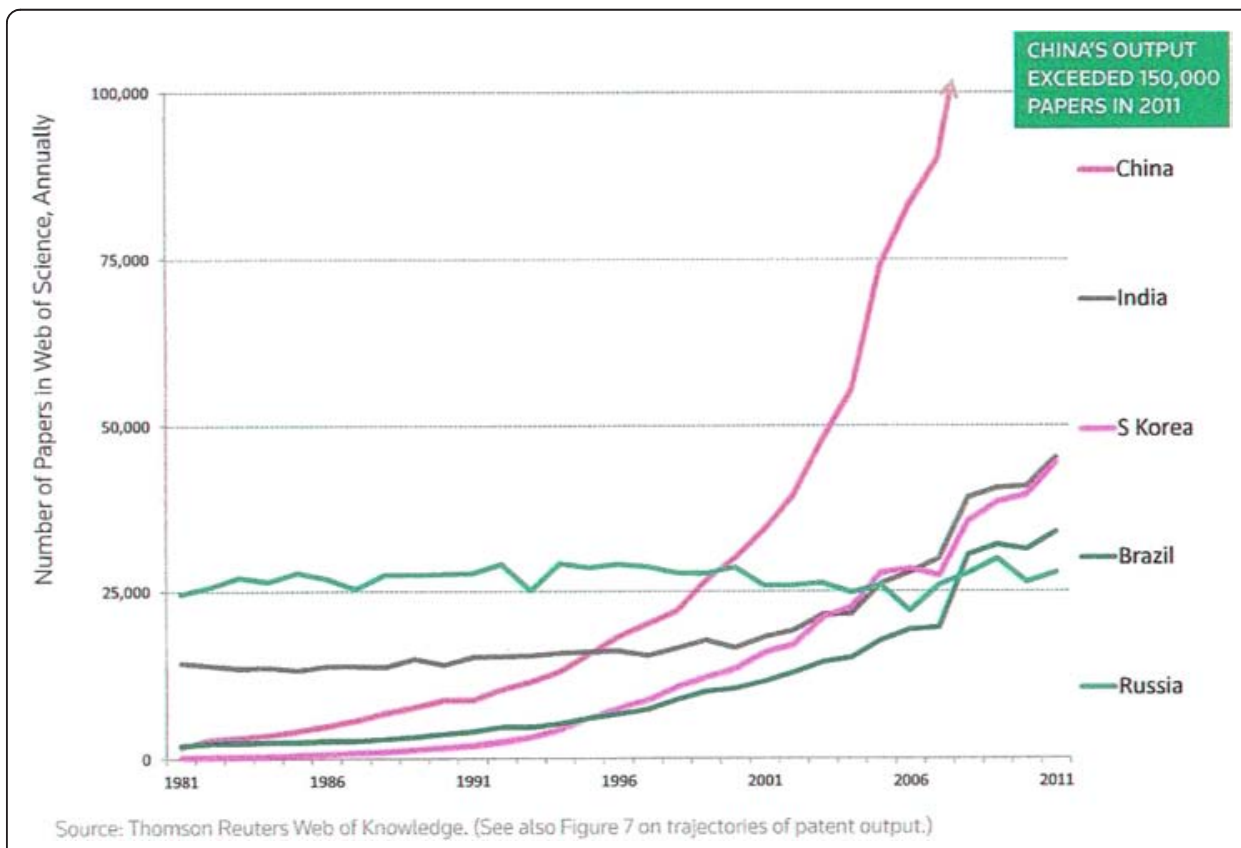

Fig. 1 Web of science publications, BRICs and South Korea, 1981-2011 
Table 3 Russian share of total global publications by field

\begin{tabular}{lll}
\hline Field & $2001-2005(\%)$ & $2007-2011(\%)$ \\
\hline Physics & 8.72 & 7.22 \\
Space science & 7.56 & 6.69 \\
Geosciences & 7.51 & 6.57 \\
Mathematics & 5.35 & 4.61 \\
Chemistry & 5.49 & 4.44 \\
Materials science & 4.06 & 3.03 \\
All fields & 2.99 & 2.07 \\
Engineering & 2.97 & 1.99 \\
Molecular biology and genetics & 2.24 & 1.91 \\
Multidisciplinary & 1.29 & 1.79 \\
Microbiology & 2.28 & 1.69 \\
Biology and biochemistry & 1.97 & 1.60 \\
Environment/ecology & 1.04 & 1.23 \\
Plant and animal science & 1.23 & 1.14 \\
Computer science & 1.21 & 0.95 \\
Agricultural science & 1.14 & 0.79 \\
Neuroscience and behavior & 0.74 & 0.65 \\
Clinical medicine & 0.68 & 0.57 \\
Pharmacology and toxicology & 0.32 & 0.56 \\
Social science & 0.80 & 0.44 \\
Psychiatry and psychology & 0.63 & 0.42 \\
Immunology & 0.35 & 0.23 \\
Economics and business & 0.20 & \\
\hline & & 0.41 \\
\hline
\end{tabular}

[Source: Kotsemir 2012: 21]

Over a period of two decades, China was able to alter the role of its academy of sciences while promoting research at universities and encouraging a significant $R \& D$ effort on the part of businesses. The shift is far from complete, and the expansion of higher education has entailed high costs and enormous risks. Yet the results are striking. The number of stand-alone research institutes has been reduced, and most of those remaining are now controlled by leaders more open to collaboration with universities and industry. Some research institutes and universities have successfully spun off businesses that maintain relationships with the "parent" institutions. Increasingly, businesses receive government support to seek assistance from research organizations (Suttmeier et al. 2006; Xue 1997; Ling 2006; Zheng and Tong 2014; Rhoads et al. 2014).

If China's reforms remain incomplete, Russia's reforms are far less complete. Many have stalled (Sobolevsky 2014). The Russian academy of sciences has never fully accepted the need for radical change (Balzer interviews). For nearly three decades, most Academy scholars have preferred business as usual. Many who favored change left the country or left science. The result has been the government deciding to radically alter the position and role of the Academy (Dezhina 2014b). A new Federal Agency for Scientific Organizations (FASO) now is reorganizing academy institutes to match government priorities. Technologies needed for modernization are to be emphasized, and science is supposed to support regional development. 
Table 4 World economic forum data, China and Russia

\begin{tabular}{|c|c|c|}
\hline \multicolumn{3}{|c|}{ Ranking in 2006-2007 and 2014-2015 } \\
\hline Indicator & 2006-2007 & 2014-2015 \\
\hline \multicolumn{3}{|c|}{ Production process sophistication } \\
\hline China & 89 & 56 \\
\hline Russia & 70 & 92 \\
\hline \multicolumn{3}{|c|}{ Innovation capacity } \\
\hline China & 43 & 40 \\
\hline Russia & 49 & 66 \\
\hline \multicolumn{3}{|c|}{ Quality of scientific research institutions } \\
\hline China & 63 & 39 \\
\hline Russia & 32 & 56 \\
\hline \multicolumn{3}{|c|}{ Enterprise funding of $R \& D$} \\
\hline China & 39 & 23 \\
\hline Russia & 44 & 62 \\
\hline \multicolumn{3}{|c|}{ Business-university collaboration in R\&D } \\
\hline China & 27 & 32 \\
\hline Russia & 54 & 67 \\
\hline \multicolumn{3}{|c|}{ Government procurement fosters innovation in advanced technologies } \\
\hline China & 21 & 10 \\
\hline Russia & 79 & 81 \\
\hline \multicolumn{3}{|c|}{ Availability of scientists and engineers } \\
\hline China & 86 & 43 \\
\hline Russia & 46 & 70 \\
\hline \multicolumn{3}{|c|}{ Patent applications (per 1 million pop.) } \\
\hline China & 49 & 43 \\
\hline Russia & 38 & 41 \\
\hline \multicolumn{3}{|c|}{ Intellectual property protection } \\
\hline China & 74 & 53 \\
\hline Russia & 112 & 107 \\
\hline
\end{tabular}

World Economic Forum Global Competitiveness Reports, 2006-2007 and 2014-2015. Ranking each year. Note that the number of countries included increased from 125 in 2006-2007 to 144 in 2014-2015

Since 2012, businesses have been required to partner with universities to develop innovation (Bychkova et al. 2015).

These changes could be successful if the Russian state is able to simultaneously stimulate and monitor the R\&D sector without stifling it. The Putin regime, however, blames the shocking decline in Russian scientific publication activity since 1990 on the "radical neoliberal reforms" of the 1990s. Russia's rulers remain convinced that greater state control is the solution. Yet Russia's position has declined further in the years since Putin came to power, despite a significant economic recovery and both the Russian government and foreign grant-making organizations allocating significant funds to support research. That much of the Russian funding is wasted or ineffective remains a persistent problem. It is particularly striking that the relatively small share of funding from foreign sources has generated more publications, these articles appear in journals with higher impact factors, and are cited more frequently (Kotsemir 2012: 16). The Russian government's decision to curtail 
foreign funding, labeling organizations engaged in support for education and science as "foreign agents," appears to be an example of self-inflicted damage. It provides a stark contrast with China's approach, where proponents of openness have more often prevailed (Zweig 2002; Jonkers 2010; Balzer 2010).

In Triple Helix terms, the most significant institutional change in both countries has been the effort to transform universities from purely teaching institutions-the role assigned to higher education in the Soviet system-into internationally competitive research organizations that partner with business to generate innovation. China has been far more successful in this effort.

\section{Universities}

The shift to priority for universities is a potentially positive development due to the special way universities derive creative energy. A culture of academic openness is one major factor. Etzkowitz (2008) notes that the advantage of universities comes in large part from regular turnover of undergraduate students, graduate students, and some faculty and research associates, stimulating constant questioning of accepted ideas. Many of the ideas generated by students are impractical or lead to dead ends. But sometimes they are winners. Students regularly force researchers to question basic assumptions.

Although a growing literature lauds innovators who dropped out of universities to create companies like Microsoft, Apple, Nintendo, and Facebook, far more innovation derives from collaborative efforts within a university context, particularly at the nexus of university talent, industry interest, and government support. Even companies founded by "dropouts," like Apple, benefitted substantially from direct and indirect government and university support (Mazzucato 2013: 111).

Both China and Russia have adopted major state programs to foster research universities and raise their stature in global rankings. China has achieved more success (Balzer 2010). The two most striking differences in Chinese and Russian efforts to develop research universities that are competitive in global rankings are the consistency of the Chinese effort compared to the chaotic Russian approach, and China's greater openness to international collaboration and learning, reflecting the behavior of epistemic communities.

In the 1950s, China identified a select group of higher education institutions as "key" (zhongdian). There were 11 universities in this elite group in 1956. It grew to 88 by 1978. In the 1990s, the government introduced several programs prioritizing research universities. In 1993, the 211 Program was designed to transform about 100 Chinese universities into world-class institutions by the early twenty-first century. Currently, 106 institutions, or about $6 \%$ of China's 1700 higher education institutions, receive special funding through the program. Recent global rankings indicate that it is achieving success (Balzer 2010; Balzer 2011). Individual case studies indicate that there is no single model for China's success, suggesting that universities must find their own paths (Rhoads et al. 2014).

While Chinese institutions have been rising in most of the major university ranking systems, Russian universities have nearly vanished, with only Moscow University retaining a rank in the top $300 .^{4}$

To raise the global prestige of universities and foster innovation, Russia has introduced a series of programs to promote elite universities (Fediukin and Froumin, 2010; 
Dezhina and Kiseleva 2008; Dezhina 2014a). In 2006-07, 57 institutions were selected for special funding for innovative educational programs. In 2009, the "research university" program selected 29 institutions, and the government also funded 7 (later 8) "Federal Universities" in regional centers across the country, while according Moscow and St. Petersburg special status, for a total of 39 institutions. In 2013, a new 5/100 program was announced, intended to raise five Russian universities into the world's top 100 by 2020 . Fifteen successful applicants were invited to submit "road maps" describing how they would reach this goal. As of September 2015, 14 had been approved.

It is striking that in contrast to China's patient efforts, each round of Russia's competition for elite status has seen the number of institutions reduced: 57 innovative programs; 39 research and Federal Universities; and most recently just 14 in the 5/100 program. As budget problems limit the funds available for education and research, the non-elite higher education institutions in Russia are finding it increasingly difficult to garner financial support. Chinese patience (or a realistic appraisal of the situation) also is clear in the time frames set by government planners: China is supposed to have world-class universities by 2050; Russia expects to achieve this by 2020 .

Russian higher education weathered the 2008-2009 economic crisis reasonably well, but the situation in 2014-2015 has been far more dire. With declining enrollments, the Russian Ministry of Education and Science has been evaluating institutions with an eye to closing or amalgamating those that fail to meet quality standards. A declining number of highschool graduates threatens a model of relying on tuition for support. At the same time, government funding for all but elite institutions is being reduced. ${ }^{5}$ The effort to internationalize is being undermined further by the devaluation of the ruble, which lost half its value between mid-2014 and mid-2015. This has made foreign publications prohibitively expensive, foreign equipment increasingly beyond reach, and foreign travel a luxury. The extent of the difficulties was apparent when the Ministry of Education and Science website posted a toll-free hotline number for students to report institutions that were illegally demanding that they pay their fees in dollars or euros (Poisk 2015).

The differences in educational quality are paralleled by universities' receptivity to innovation partnerships. While China has successfully embraced a Triple Helix ethos for universities, the research university model remains contentious in Russia, where many university and Academy scholars, particularly the older generation, eschew involvement in commercial activity. Russian businessmen find foreign R\&D partners to be more helpful than their Russian counterparts (Simachev et al. 2014: 30; Bychkova et al. 2015). Russia businesses view collaboration with research organizations primarily as a source of financing, rather than a path to long-term technology development and commercial success (Simachev et al. 2014: 29-30). Russia has a surprisingly paltry number of small and medium businesses, and few of them perceive innovation to be a practical goal (Organisation for Economic Co-operation and Development 2013a: 2).

Surveys and interviews reveal that the differing mentality of businessmen and researchers remains a major obstacle to cooperation between firms and research organizations in Russia (Simachev et al. 2014; Bychkova et al. 2015). While it is not easy to resolve this conflict, it may sometimes be turned into a creative tension. This would require the state to be less strictly focused on final results and more 
oriented to priorities of intellectual property (IP) and management systems. The prevailing bureaucratic management system inhibits mutual understanding of needs and priorities.

Conservatism is reinforced by Russia's tradition of "scientific schools" (Dezhina and Kiseleva 2009), which limits mobility across institutions, as does the practice of students remaining at the same university for undergraduate and graduate study and then as faculty. ${ }^{6}$ China has experienced similar problems, but has managed to encourage a somewhat greater degree of mobility through competitive faculty recruitment policies and the role of returning émigrés. This is one of several realms where Chinese "sea turtles" who have returned from extended periods of work abroad have helped to exert a positive influence on their "land turtle" colleagues who remained in China-a crucial difference in the behavior of the epistemic communities (Balzer 2010).

\section{Epistemic communities}

Professional communities in the two countries have responded unevenly to the processes of reform and internationalization. In Russia, the entrenched scientific community largely resists both reform and collaboration with business. Many in the Academy of Sciences insist that their mission is to devote themselves to fundamental science. Commercial considerations are viewed as alien to the pursuit of real science, constituting a crass intrusion into the search for scientific truth.

Epistemic communities must be encouraged to reform and to compete by a combination of incentives and sanctions: rewards for compliance, salary, and career trajectory penalties for resistance. Peer pressure can help enormously in encouraging positive behavior patterns, with returnees in a position to play a unique role (Zweig 2009; Zweig et al. 2006; Jonkers 2010). When scientists and educators have the option of receiving state subsidies and support, many find this preferable to competition in the free market.

The Russian Academy, like most scientific academies across the world, remains a highly conservative institution. Privileged status and generous bloc funding in the Soviet era induced most Academy members to support a system that paid researchers to devote nearly all their time to scientific work. This is not realistic in a market economy, yet the Academy leadership has consistently resisted reforms that would reduce staffing levels or encourage more researchers to add teaching to their duties. Conservatism and bureaucratic inertia often combine with self-interest to deter reform. New demands and new evaluation criteria inevitably threaten long-established status and behavior patterns.

The Chinese Academy was modeled on the Soviet one, and similar problems prevailed when reform began. Yet the Chinese government and academy have managed to find a less fraught compromise that has maintained some Academy institutes while shifting some of the financial burden out of the government budget (Xue 1997; Ling 2006).

The relationship between Russian academics and officials is complicated by an extreme variant of what might be called "the Scott Thompson factor." Beginning in the Soviet era, it became common practice for government officials to receive academic credentials, and in some instances, to gain election to the Academy of Sciences, on dubious grounds. In the Putin era, about one-third of top Russian government officials 
hold kandidat of science or doctoral degrees that were purchased. Putin and his close associates Igor Sechin, and Viktor Zubkov all defended kandidat dissertations at the Mining Institute in St. Petersburg between 1997 and 1999. Some 18 pages of Putin's thesis, the core of his chapter on "Scientific Planning," were plagiarized from an economics textbook written by two University of Pittsburgh Business School professors and subsequently published in a Russian translation by Mir publishing house (Balzer 2006; Heinrichs 2006).

China is hardly free of these problems. However, internationally oriented members of the Chinese scientific community, supported by growing pressure from returnees, have been demanding international standards of peer review and scholarly integrity. They face daunting challenges, exacerbated by the increasing demand for quick research results and rigid quantitative criteria for promotion and remuneration.

One critically important example of a policy realm where the Chinese have learned from foreign practice through the work of foreign NGOs influencing epistemic communities and government policy involves HIV/AIDS. A Chinese NGO took the lead in developing programs to wean addicts from injecting heroin (Teets 2014: 102-09). China's government, initially skeptical, eventually adopted the policies. The contrast with Russia could not be more stark. The leadership of the Russian medical community, and most Russian politicians, vehemently reject needle exchange and substitution therapy as practices that encourage substance abuse. One of the first things Russian authorities did after annexing Crimea was to close the facilities providing clean needles and Methadone, resulting in many deaths. Rejecting international best practices in the life sciences is one example of the ways Russian epistemic communities thwart even well-funded programs.

\section{Funding}

Russia and China have both significantly increased funding for science and education, with quite different results. The state remains the dominant source of financial support in Russia, and many Russian analysts continue to measure the nation's status in science on the basis of the amount the government spends. In the 1980s and 1990s, as China opened and internationalized, private R\&D investment slowly began to increase, though China's mostly low- and mid-tech manufacturing did not demand cutting-edge science. The government established explicit funding guidelines privileging "practical" research over basic science. Over the past 20 years, Chinese gross expenditure on R\&D (GERD) has skyrocketed, due largely to a 25 -fold increase in business expenditures (BERD), concentrated heavily in manufacturing research.

Increased spending is more effective in a reformed Chinese science system that is transitioning away from the Soviet model toward competitive grant funding and publicprivate partnerships. The results have been visible in a growing publications record (Fig. 2), an impressive industrial capacity (Breznitz and Murphree 2012; Nolan 2014; Zheng and Tong 2014), and increasing evidence of innovation (Lewis 2013; Jakobson 2007; Strategy\& 2014; Huang and Sharif 2015; McKinsey 2015). Business support for $R \& D$ is reflected in China's impressive growth in patenting activity and in the related data on utility models and industrial designs (Figs. 3 and 4). One telling indicator is that between 1985 and 2005, the proportion of "triadic" patents, those filed in the USA, 
Europe, and Japan, that were also filed in China grew from 9 to $61 \%$. In Russia the proportion remains below $20 \%$ (Huang and Sharif 2015).

In contrast to China's increasingly diverse system of financing research and innovation, Russia's R\&D sector remains dominated by government financing (Fig. 4). The collapse of the USSR produced an economic crisis that devastated Russian science funding. Many of Russia's best scientists moved to the West; many others abandoned the profession for better-paying alternatives. In the 1990s, foreign non-profits and governments stepped in with substantial funds to "save Russian science." Following the August 1998 economic crisis, Russian government and business investment in research began to recover, and has grown markedly since 2000. About $70 \%$ of Russian science funding comes directly from the state, mainly in the form of block allocations to research organizations. Funds for universities were also increased substantially. But rather than the emergence of a selfsustaining, innovation-oriented research enterprise, Russia continues to experience a battle between reformers seeking a more competitive system of funding and entrenched interests lobbying for increased government support through "traditional" arrangements.

Russian R\&D statistics consistently focus on inputs, a legacy of Soviet emphasis on investment. Yet the crucial question is not how much is spent but rather how effectively the funds are utilized and what results are achieved. Here, the contrast between China and Russia is stark, raising questions about state capacity and agents' behavior.

While until 2014 the elite Russian universities were allocated substantial funds, this financing was narrowly focused, limiting the scope of what university administrators could do with the money. Dezhina (2014a) describes poor overall performance and funding mostly from government via outmoded structures. These conditions are related. Russian grant and special program funding are encumbered by excessive controls that promote waste while failing to curb corruption. Much of the money is spent badly. Universities have an absurd lack of discretion in spending any funds the government provides. The money is allocated to excessively rigid categories, sometimes arrives halfway through the budget year, yet is given on a "use it or lose it" basis that impels

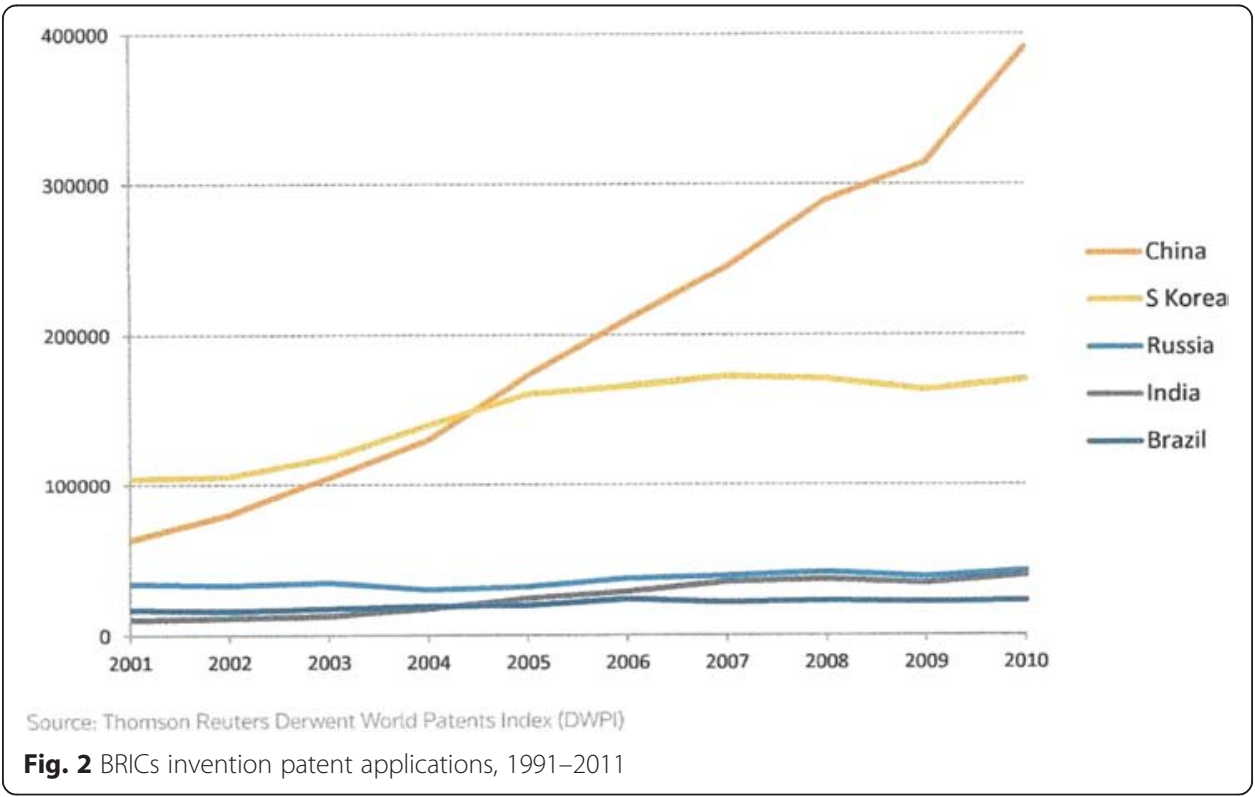




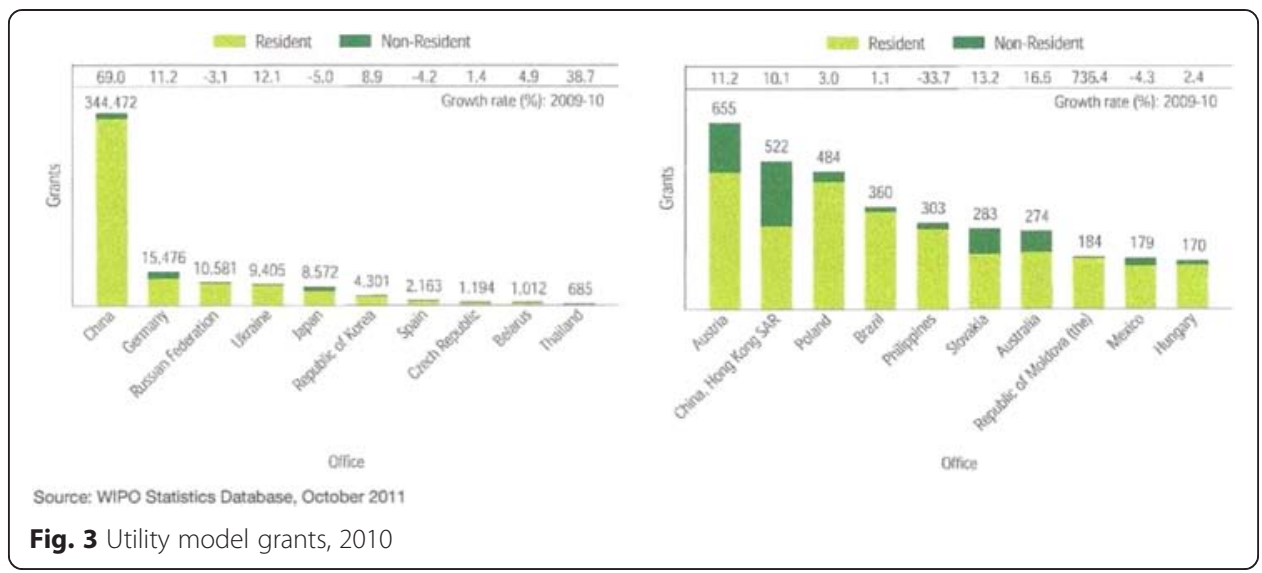

institutions to find ways to spend the funds quickly so that they may request more support in the next budget cycle. ${ }^{9}$ Accounting procedures are time-consuming. Institutions that receive a major government grant sometimes must hire a special bookkeeper just to deal with the paperwork (Balzer interviews). China's university administrators are held accountable for results, but have been accorded far more leeway in how they use funds to achieve those results (Zhou 2012; Rhoads et al. 2014).

Simachev et al. (2014: 31) suggest that generous budget financing for research at Russian universities reduced their motivation to develop collaborative research with business, a situation reinforcing the cultural chasm between business and research. The business-university separation presents a long-term challenge to creating a vibrant Triple Helix system.

Foreign funding sources played an important role in supporting Russian science and education in the 1990s and into the 2000s (Graham and Dezhina 2008). ${ }^{10}$ China also has received significant foreign support for research (Zweig 2002), and multinational corporations have established research centers to take advantage of (less expensive) local talent. China has benefitted from a massive inflow of industrial research support,

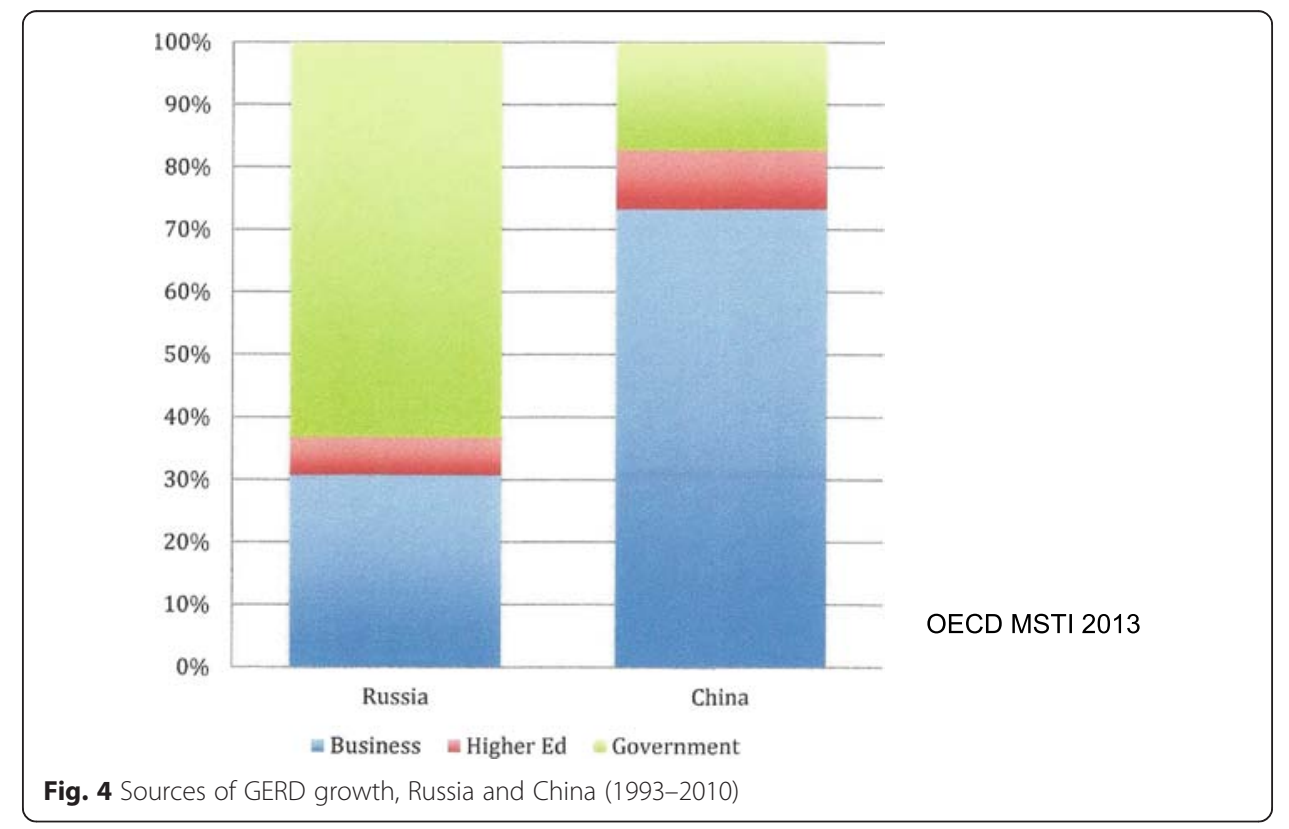


with ten times the number of foreign R\&D facilities compared to Russia (Organisation for Economic Co-operation and Development 2013b; Sun et al. 2008).

European and American universities have developed a broad range of collaborative programs in Russia, but Russian policy has become increasingly contradictory. On the one hand, universities are still rated on their progress in internationalization, and scholars are rewarded for publishing in international journals. On the other hand, since the Crimean invasion, international contact has been more fraught. Russian scholars are being told to develop cooperation with Chinese colleagues and institutions (Balzer interviews, 2014 and 2015). Visa regulations for visiting Americans are being enforced more rigidly.

Most ominously, Americans and other foreigners who assumed important positions in Russian educational and research institutions are departing or being forced out. ${ }^{11}$

The rise in Chinese spending on research and development over the past 20 years is nothing short of remarkable (Askonas 2013; Rhoads et al. 2014). China's gross expenditure on R\&D (GERD) increased from $\$ 7.5$ billion in 1991 to $\$ 178.2$ billion in 2010, a more than twenty-fold increase. While this has been driven in part by an economy that is fifteen times larger than in 1991, expenditure on R\&D as a percentage of GDP has trebled. The growth in China's GERD thus reflects an increased role for R\&D within the economy and increased importance accorded to China's rise from a low-wage labor economy to a competitive global player. China's GERD has risen from $0.75 \%$ of GDP (on par with many developing countries) to a respectable $1.75 \%$, only slightly below the European Union average, and is projected to grow further. This leap in research spending is a feat unique among BRIC countries. From 1993 to 2010, industrialsourced BERD accounted for $70 \%$ of the growth in Chinese research spending; in Russia, $65 \%$ of GERD growth came from government spending (Fig. 4, Organisation for Economic Co-operation and Development 2013a).

Both countries have serious problems with accountability of local officials and corruption. China appears to be coping rather better. ${ }^{12}$ China's spending has far more often produced visible results: universities rise in global rankings, scholars publish in international peer-reviewed journals, and businesses improve the products available to consumers. We find an explanation for the difference in the behavior of epistemic communities and government agents responding to the nature and quality of the state and the incentive structure it creates.

\section{The role and quality of the state}

Breznitz (2007) demonstrates that states may encourage innovation in a variety of ways. Crucial is that state agents be, on balance, more supportive of development than dysfunctional or predatory. Russian policies overwhelmingly encourage short time horizons and behavior that satisfies leaders in Moscow. China's leaders certainly do not encourage policies that contradict their views, but they have been far more pragmatic in accepting deviations that produce positive economic results (Rochlitz et al. 2015; Zweig 2002; Florini et al. 2012; Vogel 1989; Zhou 1996).

The incentive structure in China, particularly in the 1980s and early 1990s, but also more recently rewards local officials for improving the local economy, at least statistically. ${ }^{13}$ The Chinese incentive structure has encouraged economic growth in (at least) 
three ways: economic success has meant career advancement; regions were allowed to retain a share of the profits from growth until the mid-1990s; and a growing revenue stream meant officials controlled a larger pie from which to pilfer (provided they did not take so much that they stifled growth). Anti-corruption efforts have helped to limit the extent of predation (Wedeman 2012). The Chinese system is far from an ideal development model, but it has been remarkably successful, and it is enormously attractive to authoritarian rulers elsewhere.

The Russian state has been far less effective. Few regions have become industrial centers, much less exporters of anything but raw materials. Simachev et al. (2014) suggest that the Russian state effort to compensate for the underdeveloped institutional space encourages firms to be excessively involved with the state, further inhibiting development of institutions. Tax incentives for R\&D have accomplished little. They conclude that: "The state thus far has not developed the skills to introduce soft, motivating instruments. The emphasis on financing is excessive." Russian government programs are "hard," not "soft," and have not encouraged genuine partnerships. ${ }^{14}$ Chinese officials in some regions were far more flexible, giving rise to the phenomenon of formally socialist (Red Hat) enterprises that enjoyed substantial autonomy.

While China has built a dynamic IT industry (Segal 2003; Y. Zhou 2008; Ling 2006), the architects of Russia's Skolkovo project to foster high technology have ignored Etzkowitz (2008: 87) warning against assuming that Silicon Valley and Route 128 are replicable. The combination of factors that made MIT and Stanford unique is not easily reproduced. North Carolina's Research Triangle did succeed, but moving a major federal lab is not a common event. Etzkowitz notes that "it took decades to successfully create a science park, undiluted by general industrial ventures." More frequently, officials become impatient and the science parks become industrial parks, housing factories and professional office buildings. ${ }^{15}$ They may earn money, but do not become innovation hubs. The UK, for example, did not succeed with science parks; perhaps they lost patience.

Etzkowitz suggests that visitors who came to Stanford in the 1970s did not always understand that "the firm-formation process they were observing was already the result of 50 years or more of work." Before it became an innovation hub, the area was simply an industrial park, intended to generate money. Etzkowitz goes on to point out that many of the firms that chose to locate there were already close to the university: "The park was the end result, not the starting point, of a process of encouraging the creation of an organizational capacity and ethos to form firms around the university."

Russian leaders clearly have little patience; their Chinese counterparts do better in this realm. In 2015, McKinsey published a report on Chinese innovation noting that China was doing relatively well at consumer-focused and efficiency-driven sectors, while pointing out the challenges to successful performance in engineering-based and science-based industries (McKinsey 2015: 10). They concluded that "China has the potential to build on its strengths in innovation and become a global leader" (McKinsey 2015: 7). Not surprisingly, some commentators focused on passages about Chinese imitation being more significant than innovation to conclude that China is stuck in a "follower" role. Breznitz and Murphree (2012) argue that being No. 2 is not a bad situation. But, the McKinsey report tracks with other recent studies suggesting that in 
some sectors China is moving in the direction of serious innovative capacity (Jonkers 2010, Lewis 2013, Walsh 2014).

No one outside of Russia is publishing extended reports on Russia's innovation potential. The discourse within Russia consists of extensive criticism of shortcomings along with some "blue sky" analyses of what might be possible in some imagined future. While it is not possible to discuss the global economy without major attention to China, Russia, generating less than $2 \%$ of global GDP, is an afterthought. Outside of the energy and military sectors, the fate of Russia's economy is significant primarily to a few neighboring nations.

The relative success of Russian and Chinese state practices and innovation programs may be seen in the results of substantial efforts by both governments to promote nanotechnology.

\section{Nanotechnology}

In the early 2000s, nanotechnology was accorded priority status in Russia's plans for science-based economic development. President Putin suggested that Russia should capture its fair share of the projected multi-trillion dollar global nanotechnology market. China, with far less fanfare, also has given nanotechnology a high priority. Based on publications and patents, China's lower-key approach appears to be generating greater returns (Fig. 5).

Russian capacity in nanoscience may be traced back to intensive Soviet investment in materials science and chemical research. While disadvantaged by underinvestment in laboratory equipment and a comparatively closed scientific system, Soviet scientists nonetheless held their own in the newly emerging field of nanoscience, contributing foundational work in quantum dots, heterostructures, carbon nanotubes, and graphene (Josephson, 2010).

Despite this early success, nanotechnology was a questionable choice as a priority field for Russia. Soviet S\&T was notoriously "stovepiped," with scientists rarely working

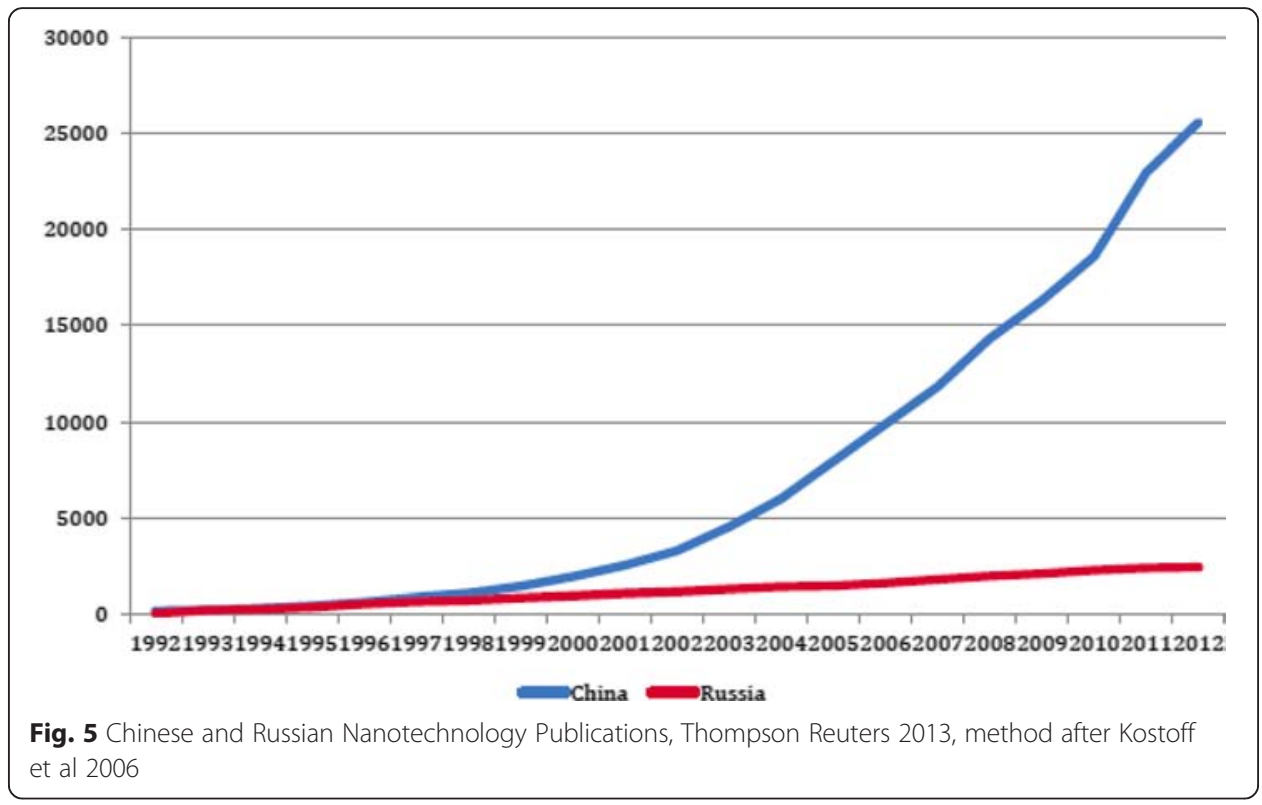


across disciplines. Yet much nanotechnology research involves inter-disciplinary collaboration in fields such as bio-physics.

In 2006, responding to the launch of the US National Nanotechnology Initiative in 2000, Russia announced a "Program on Coordination of Nanotechnology and Nanomaterials Development" (Neufield 2011). The following year, the government introduced two important research initiatives: a National Nanotechnology Network (a government R\&D initiative to encourage nanoscience research in Russia's universities and institutes) and the Russian Corporation of Nanotechnologies (RusNano), a technology investment company to foster public-private partnerships and spin-off commercialization surrounding nanoscience (Westerlund 2011).

In 2008, as part of Dmitry Medvedev's modernization initiative, nanoscience was reaffirmed as a priority area for research investment. These efforts ranged from substantial research grants for scientists working on nano-scale projects to commercialization and entrepreneurship initiatives. The budgets involved were generous. For more than 4 years, Russia led the world in nanoscience research investment on a Purchasing Power Parity (PPP) basis (Westerlund 2011). ${ }^{16}$

If throwing money at the programs were an adequate strategy, Russia would be doing extremely well. However, Russia's substantial investment thus far has produced neither an increase in significant publications nor any visible breakthroughs in technology (see Fig. 5). ${ }^{17}$

China's effort in nanoscience has been in many ways the inverse of Russia's. Over the past 30 years, sustained investment in scientific enterprises, reform of China's university system, and dynamic research and development growth have moved China from a backwater to a leader in applied science. This remarkable result in many ways parallels the changes to the Chinese economy, with regional policy experimentation driving economic openness and increased global integration.

Recent studies demonstrate the rise in China's stature in nanotechnology publishing and patenting, while complicating any simple explanation for the success. Applebaum et al. (2011) emphasize the role of the state in China's nanotechnology achievements, in particular through financing basic and applied research, stating that China "still suffers from a lack of private investment capital." This assessment contradicts the data on business funding of R\&D in China, which has grown steadily both in the general economy (Organisation for Economic Co-operation and Development 2013b) and for nanoscience (Harper 2011). The discrepancy stems in part from some of the business financing of $R \& D$ coming in the form of government funds passed through the private sector.

Other research confirms the growing return on China's investment. Li et al. (2014), Wang et al. (2012), and Mehta et al. (2012) all find Chinese nanotechnology researchers actively publishing, with a growing number of the publications representing collaborative work with Chinese and other colleagues outside China. Bhattacharya and Shilpa (2012) extend the analysis of China's growing role beyond bibliometric indicators to include innovation. They find that China has performed quite well in establishing standards and developing products and processes. ${ }^{18}$ Motoyama et al. (2014) describe the diffusion of nanotechnology research beyond Beijing and Shanghai to a growing number of Chinese nodes.

The nanotechnology case illustrates the markedly different results achieved through state programs and increased spending in Russia and China. China is now in 
discussions with Russia about providing financing for some of Russia's nanotechnology projects. As in many recent Russia-China negotiations, price and performance will be important factors. Will China insist on conditionality regarding the monitoring and effectiveness of Russian spending? In the summer of 2014, conversations with social and natural scientists in Moscow and St. Petersburg almost always included some comment about their being told to focus on China and even to learn Chinese. Anecdotal evidence indicates an increase in Chinese universities and technology companies hiring Russians, either as staff or consultants (Zhdanov 2013; Qi 2015).

Space does not permit a discussion of the life sciences, but available evidence indicates a similar situation in this equally crucial realm of scientific activity (Jonkers 2010; Rekord 2013; Sagieva 2011; Roffey 2010).

\section{Conclusion: explaining China's relative success}

Many nations that profited from the expansion of global trade in the 1980s have failed to develop robust R\&D sectors or technology-based industry. Few of them, however, began with the massive scientific-technical base created in the Soviet Union, and none has spent as much as Russia on the effort. Why is China outperforming Russia in so many ways?

Attempts to answer this question have emphasized government policy, historical continuity, geography, and initial conditions. Others cite Party control, China's strength in the sciences earlier in its history, proximity to dynamic innovation clusters in Asia, and the advantages of backwardness. None of these explanations withstands a comparative test (Balzer 2008). ${ }^{19}$ Rather, the explanation involves incentives to transform institutions and practices, focused in particular on government agents and epistemic communities.

If China's success were due to state policy, then we should expect the state sector to lead the economy. However, it does not. China's "economic miracle" has been overwhelmingly a story of growth outside the state sector, even if connections to the Party and State have often been crucial to success. Lardy (2014) finds that the private sector is not only more vibrant and productive, but also accounts for a greater share of China's economy than official statistics suggest. Hong and Nong (2013) calculated that if all the subsidies, low-interest loans, and discounted inputs are tallied, most Chinese SOEs are failing to generate any profits, and many are loss-making.

Historical continuity arguments fail to account for significant interruptions in performance, and the lack of a corresponding "return to normal" in other nations with long histories. How does the impressive history of Chinese inventions recounted by Needham explain China's lagging behind Japan, Korea, and Taiwan in the twentieth century? It took China centuries to begin to restore the role it played in the world before the Ching, and China's role today is quite different. Developing a role in global technology networks requires identifying niches and learning how to fill them. No nation automatically returns to a "lost" status from its earlier history due to some cosmic process that restores "natural" positions.

Geography is equally problematic. Proximity to Asia is not necessarily more beneficial than proximity to Europe. For all the talk about Asian industrial clusters and dynamism, Europeans are still wealthier, and Germany is certainly as valuable a partner as Japan. 
Many accounts of China's remarkable economic and industrial rise have emphasized some version of the "advantages of backwardness." Late industrializers have the benefit of learning from, copying, and stealing from the developed nations. But, not all underdeveloped nations develop. Emphasizing peasants not protected by a welfare system, (Sachs and Woo 1994) explains neither the development problems in Latin America, India, and Africa nor the success in Central Europe and the Baltic nations that shared Soviet-style systems.

For some economists, Russia's becoming a hydrocarbon-exporting petro-state is a convincing explanation. But Norway, with a far less impressive scientific tradition, has managed its resource boom far better. Mexico, with (until 2014) a state oil monopoly and much less claim to knowledge economy status, has a more diversified economy than Russia.

A less sweeping but more plausible explanation involves China's central government under Deng promoting reform, some regional officials pushing the reforms further and faster than Beijing intended, and Beijing accepting successful development rather than insisting on control. The Chinese state did not accomplish economic development, but did facilitate it. Coalitions of government reformers, local cadres, successful entrepreneurs, and domestic and foreign investors managed to consistently face down challenges to reform (Zweig 2002; Howell 1993; Pei 1994). In an environment offering incentives, many Chinese academics and researchers embraced opportunities provided by openness. Some professionals, including many with experience abroad, pushed for internationalization for careerist and material reasons as well as to promote development (Zweig 2002). No comparable social forces have emerged to promote sustained internationalization in ostensibly "democratic" Russia.

If any of China's "initial conditions" made success possible, it was beginning reform immediately after the Cultural Revolution, when academic and political elites had been "sent down" in droves and lacked professional self-confidence. This presents a sharp contrast to Russia, where the university and academy scientific communities were strongly entrenched when Gorbachev came to power and have largely resisted reform (Balzer 2013). Putin has in many ways encouraged their conservatism.

In June, 2014, Balzer spoke with Andrei Fursenko, former Minister of Education and Science and now advisor to President Putin on these issues. In the course of the conversation, Balzer mentioned his comparison of China and Russia, emphasizing Chinese willingness to learn compared to Russian resistance to being tutored by anyone. Fursenko immediately launched into the following monologue:

An Iranian scientist writes an article on nanotechnology, has someone check the English, and sends it out for peer review to an international journal. He gets back some critical reviews, usually suggesting major changes, and uses the information both to improve the article and improve his/her research. He might have to do this several times before getting a "revise and resubmit" that indicates the article has a reasonable chance of being published. The Iranian scientist makes the requested revisions, and publishes the article. A Russian Academy of Science nanotechnology specialist sends a manuscript out for review, gets critical comments and suggestions for revisions, decides the reviewers are idiots who do not understand his work, and publishes the article in Russian in a journal where everyone knows him. No 
improvement; no learning. Russian scholars simply ignore the feedback. This is why Iran ranks $7^{\text {th }}$ in the world in nanotechnology publications, while Russia ranks $14^{\text {th }}$.

One year later, in another interview in Moscow, Fursenko stated that for Russia, the era of learning from the West was over, proclaiming that "Americans are not capable of accepting anyone who is not willing to be an obedient child. We are tired of this." The change within 1 year is startling, and suggests a significant turn inward. Fursenko added that this "will last for 20 years."

Many of the academics most strongly supportive of reform and most thickly integrated with the international community have left Russia. Russia has not matched even China's moderate success in getting some of them to return (Balzer 2010). This highlights a key factor in Triple Helix analyses: the role of timing and sequencing in determining what effect changes in any aspect of the innovation system will have. Without the weakening of the Chinese scientific establishment in Mao's final decade, Deng's reforms would have encountered greater resistance. Reform and openness might still have prevailed, but the path would have been longer and more costly.

China's greater success in reconfiguring the Soviet-type R\&D system and integrating research and educational institutions with technology businesses stems from a combination of factors: upgrading the status and quality of at least some universities by making them research centers as well as training facilities; introducing competitive funding and peer review; encouraging regional development through career incentives and revenuesharing; and supporting effective international linkages. Perhaps most important, successful regional development in China has generated industries that have increasingly sought improved technology through cooperation with research institutes and universities. China is now shifting from the 1970s model of providing cheap labor for Japan, Taiwan, and South Korea as those nations moved up the value-added production chain. Some Chinese firms now seek lower-wage labor in Cambodia, Burma, Africa and elsewhere as they move to higher value-added activities (Davies 2013).

Willingness to learn and pragmatism accompanied by thick integration with the global education, scientific and industrial communities have been crucial to China's success. The Chinese academic community has been more willing to adopt global best practices and accept major reforms. The process has hardly been linear or devoid of conflict. Success has been driven by collaboration between government officials and members of the Chinese academic and business communities who perceive globalization as the key to China's development. They have been aided by Chinese who have returned after spending significant time abroad, and who insist on global standards if they are to work in China (Jonkers 2010). Moreover, a strong manufacturing base provides manifold opportunities for university-industry collaboration, as manufacturing generates problems that require scientific expertise to solve, creating space for creativity and theoretical insights outside of the ivory tower (Block 2011).

The China story should not be idealized. The process has been difficult and disruptive. Not everyone supports the changes. Every reform produces new "winners" who may resist further change (Hellman 1998). Corruption remains a problem, and the pressure to publish and patent has encouraged abuse. Some of China's requirements for publication compel scholars to substitute quantity for quality, while annual quotas for publications may deter scientists from publishing truly important articles that 
require substantial time. A Chinese scientist did recently share the 2015 Nobel Prize in physiology - a major goal of China's science program—but Tu Youyou was a retired specialist in traditional medicine who was not involved in the government's priority projects.

Our greater optimism regarding the Chinese case stems not only from China's more impressive trajectory in publications, patents, and technology-based industry, but also from China's far greater reliance on bottom-up development, a key driver of Triple Helix success. Chinese regions have been given significant leeway to find successful development strategies, and frequently their success has resulted in changes in government policy (Zweig 2002; Zhou 1996; Nee and Opper 2012; Florini et al. 2012). Some enterprises, entrepreneurs, researchers, and educators have managed to find ways to improve the economy. The state, at least until Xi Jinping became President, General Secretary, and Chairman of the Central Military Commission, played an increasingly less dominant role. Many Chinese officials adjusted to the importance of facilitating rather than controlling.

Nothing guarantees that China's success will continue. Since 2012, the country has been undergoing a "Xi change." Along with a serious campaign against corruption, Xi Jinping has sought to increase CCP involvement in many areas of Chinese life and exert greater control. These policies, while ostensibly aimed at providing more balance and equity, entail the risk of stifling the bottom-up and private initiative that have been responsible for much, and probably most, of China's success.

Ironically, many of Xi's policies look increasingly similar to Putin's. Russia under Vladimir Putin remains excessively focused on control and promoting the state sector. There has been far less learning. Bottom-up development is not only more effective, but also less expensive than top-down programs. Large state programs invite corruption, and failure entails high costs. Small, bottom-up projects may have a high failure rate, but the costs of any individual failure are far less.

Though both Russia and China inherited state-centric innovation systems, China has done far more to adapt to a Triple Helix environment. Government policy has encouraged cooperation: Businesses invest, universities collaborate, SMEs innovate.

The data presented by Simachev et al. (2014) go a long way toward explaining the absence of more than "double helixes" in Russia discussed by Dezhina and Kiseleva (2008). That a double helix may be stable while a triple helix is dynamic raises an important issue for authoritarian regimes that emphasize control. If Dezhina and Kiseleva are correct that Russia has not developed more than a double helix in its innovation system, this may well suit the bureaucratic authoritarian preference for predictability and stability, rather than the permanent dynamic flux inherent in a triple helix system.

The major question facing China is whether the coalitions favoring reform and openness will continue to prevail over vested interests and efforts to increase Party/State control. In Russia, the Soviet legacy still renders Russian professionals and policy makers less inclined to learn, while Putin's turn to nationalism enhances a sense of exceptionalism that will prove painfully self-destructive if it continues to disrupt linkages between Russian and global science. Shifting the state's role from a control mechanism to a facilitator is not an easy transition, but it remains no less crucial for being elusive. Thus far, China's more pragmatic embrace of a "Triple Helix model with Chinese characteristics" is highly instructive in comparison to Russia. 


\section{Endnotes}

${ }^{1}$ Here, "select for" has a technical meaning borrowed from evolutionary biology—not that businesses intentionally "innovate" toward profits, but rather that the business innovations that survive various environmental pressures are those that make a profit.

${ }^{2}$ There have been exceptions in Russia. Prusak in Novgorod in the 1990s was able to attract significant foreign investment by battling the mafia. Antonov has successfully created an auto parts industry in Kaluga. But, these few exceptional cases in Russia pale in comparison to the multitude of successful local economic projects in China (Zweig 2002; Nee and Opper 2012; Byrd and Lin 1990; Teets 2014).

${ }^{3}$ Among BRIC countries, India rose from 13th to 10th; Brazil rose from 17th to 13th.

${ }^{4}$ Balzer (2010) reviews the performance of China and Russia in the international ranking systems. Russia's universities have done less well since 2009, when the Times Higher Education rankings ceased to include "reputation" as one of the criteria. In 2014, Moscow University fell to the third 100, and no other Russian universities were among the Times top 500. Russia's decline in the global rankings has come despite the significant resources allocated to elite universities. Losing international status has encouraged a growing number of Russian education officials and administrators to advocate developing Russia's own system of ranking universities, focusing on criteria that are more "fair" to Russian conditions. A first attempt at "a university ranking with Russian characteristics" conducted in 2008 included number of alumni, number of students, and number of specialties among the five criteria for ranking institutions. Not surprisingly, Moscow University placed 5th in these rankings. The emphasis on technical specialties was clear in MIT and Cal Tech being ranked numbers one and two. While few Russian institutions made the top 200, quite a few ranked among the 430 included in the list: 42 or $9.7 \%$ of the world's top universities were Russian. The Russian approach provides a stark contrast with the Shanghai Jao-Tang university ranking system, which if anything downplayed the status of Chinese universities in its early years. The Shanghai ratings have become accepted as one of the major university ranking systems.

${ }^{5}$ Balzer discussions with colleagues from several of the elite Russian universities at ASEEES Annual Meeting, San Antonio, Texas, November 2014, and in St. Petersburg, December 2014. Several faculty and administrators noted that budgets were being frozen or slightly reduced for the current academic year. This was prior to the dramatic decline in the exchange rate of the ruble in December 2014, which will significantly curtail the ability of Russian organizations to finance travel abroad or meet their commitments to fund travel and work by foreign colleagues.

${ }^{6}$ Balzer interviews and conversations during meetings and site visits related to the Basic Research and Higher Education Program, 1998-2008.

${ }^{7}$ Scott Thompson, the CEO of Yahoo, was forced to resign in May 2012 when it became known that he had "padded" his resume. For many years, Thompson had claimed that his undergraduate degree was in both accounting and computer science, when it was only in accounting.

${ }^{8}$ Balzer served as Director of the International Science Foundation, George Soros's $\$ 100$ million program for science in the former USSR and Baltic states. He also served from more than a decade on the Governing Council of the Basic Research and Higher Education Program, a joint MacArthur Foundation, Carnegie Corporation and Russian 
Ministry of Science and Education program that established 20 "Research and Education Centers" (Nauchno-obrazovatelnyi Tsentry) at Russian universities.

${ }^{9}$ During implementation of the BRHE program, the funding levels went from being spectacular by Russian standards to being barely noticeable. In 1999, $\$ 300,000-\$$ 500,000 for an academic department for one year was a fortune at most Russian universities. By 2010, it was relatively modest. But even amounts as small as $\$ 50,000$ were considered tremendously important because the funds came with few restrictions and were "fungible" - that is, they could be used for whatever was needed to accomplish research projects, rather than having to fit narrow spending categories. Bychkova et al. recount businessmen participating in the Russian government's program demanding industry-university collaboration in innovation telling them that the time required to comply with bureaucratic reporting demands is so excessive that they would never involve themselves in another collaborative project.

${ }^{10}$ The ISF and BRHE programs alone put about $\$ 300$ million into support for Russian education and science.

${ }^{11}$ Kendrick White, who served as Pro-Rector for Innovation at Nizhnyi Novgorod University, was denounced by Dmitry Kiselev on the "Vesti Nedeliu" program on June 28, 2015. Two days later, the University's Rector announced that White would be leaving the position. When asked directly about this a few days later, President Putin's advisor on Education and Science responded that foreigners should not be allowed to occupy administrative positions at Russian universities because these jobs involve personnel issues, including staff who worked in the Soviet era. That a Presidential spokesman would invoke Soviet work habits 25 years after the demise of the USSR speaks volumes about the Putin environment.

${ }^{12}$ The contrast in coping with corruption is clearly demonstrated by two recent monographs. Andrew Wedeman's (2012) Double Paradox describes a significant, if still flawed, effort by China's leadership to constrain corruption. Karen Dawisha's Putin's Kleptocracy (Dawisha 2014) portrays a regime immersed in corrupt practices and directing its anticorruption overwhelmingly at political opponents and whistle-blowers.

${ }^{13}$ Some scholars have questioned the validity of claims that Chinese local officials are promoted primarily on the basis of their economic performance. Other criteria are certainly involved, but no less an authority than President Xi Jinping has recently stated that the reliance on GDP as the basis for evaluating performance is not a good policy. Some regions have begun to experiment with quality measures including the environment and income equality.

${ }^{14}$ Similar conclusions are drawn by Bychkova et al. 2015.

${ }^{15}$ In Moscow, the new "financial center" now houses a youth hostel in one of the high-rise buildings intended for financial professionals (Kramer 2014).

${ }^{16}$ For the Nanotechnology Network, 27 billion rubles (about $\$ 1.1$ Billion at the time) were allocated over 2008-2010 and, for RusNano, over 218 billion rubles (about $\$ 9$ billion at the time) over 2008-2015. While a small portion of RusNano's funding was disrupted by the financial crisis in 2008, these two investments were still more than enough to make Russia the world's top nanotechnology spender from 2008-2010 (Harper 2011). After 2006, the percentage of Russian R\&D funded by the government increased by $5 \%$, and government outlays increased by more than $\$ 1$ billion a year during 2005-2008. The percentage of $R \& D$ expenditure spent on basic (rather than 
applied) research also began trending upward, reflecting Russia's commitment to restoring its place in global science through breakthroughs in nanotechnology.

${ }^{17}$ Russian emphasis on production inputs and neglect of either process or outputs bears an obvious affinity to Soviet era scientific practices.

${ }^{18}$ The emphasis on process innovation tracks with the emphasis on process rather than new product innovation in Breznitz and Murphree (2012). They have suggested that China could do quite well as a second-tier innovator, avoiding the risks of new product innovation while emphasizing its strengths in process innovation and the introduction of lower-cost versions of popular technology. China's proven industrial capacity and enormous domestic market give it strong advantages in pursuing this strategy. The "Red Queen" model does depend on someone else (the USA in particular) providing the new product innovation that underlies the model. More important, it plays down national pride, the prestige (and ego) of scientists, engineers, entrepreneurs, and politicians; not to mention the demands of an increasingly assertive military for cutting-edge technology. Russia under Putin is no less concerned with military capacity. Putin (1999) believes that only the military had world-class technology in the Soviet era, and that it managed to preserve some of this capacity. However, it is difficult and expensive to sustain a separate "island" of advanced R\&D for the military without a parallel civilian science and technology. Debate over how far ahead a separate military sector might be was prominent in the Soviet era, and we learned that the real advantage of Soviet military technology was its massive share of resources (2/3 to 3/4 of GDP) and its ability to "milk" the civilian sector (Balzer 1985; 1989). Russia is trying to upgrade its military-industrial complex, but it is proving to be a significant challenge (Balzer 2015).

${ }^{19}$ Another explanation popular in Russia is the dislocation stemming from communist policies. This, however, fails to account for the capacity of nations like Poland or Estonia to successfully reform a Soviet-style system, not to mention China.

\section{Additional file}

Additional file 1: Translation of the abstract into Arabic.

\section{Author details}

${ }^{1}$ Department of Government, ICC 681, Georgetown University, Washington, DC 20057, USA. ²Department of Politics and International Relations, University of Oxford, St Cross College, St Giles, Oxford OX1 3LZ, UK.

Received: 2 March 2015 Accepted: 11 December 2015

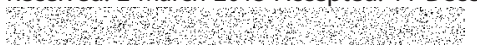

References

Applebaum R, Parker PR, Cao C (2011) Developmental state and innovation: nanotechnology in China. Global Networks 11 (No. 3):298-314

Askonas J (2013) Republics of Science: A Study of Science Policy in China and Russia through Developments in Nanoscience. BSFS (Hons) Thesis. Georgetown University: Washington, DC.

Balzer H (1985) "Is Less More? Soviet Science in the Gorbachev Era" Issues in Science and Technology, Summer, p 29-46.

Balzer H (1989) Soviet Science on the Edge of Reform. Westview Press, Boulder, CO.

Balzer H (1993) "Science, Technology and Education in the Former USSR" in U.S. Congress. Joint Economic Committee. The Former Soviet Union in Transition, Vol. 2. USGPO, Washington, DC, p. 889-908.

Balzer H (2006) "Vladimir Putin's Academic Writings and Russian Natural Resource Policy", Problems of Post-Communism, 53(1):48-54.

Balzer H (2008) Russia and China in the Global Economy, Demokratizatsiya 16 (No. 1), Winter 2008, p. 37-48.

Balzer H (2010) Obuchenie innovatsiiam v Rossii i v Kitae (Learning to Innovate in Russia and China). Pro et Contra. English Version available as Working Paper No. 2011-17, Mortara Center for International Affairs, Georgetown University, p. 52-71.

Balzer H (2011) "Russian Higher Education to 2020," Russian Analytical Digest. No. 95, p. 2-5. 
Balzer H (2013) Authoritarianism and Modernization in Russia: Is Russia Ka-Putin?. In: Steven Blank (ed) Politics and Economics in Putin=s Russia. U.S. Army War College, Carlisle, PA, p. 125-74.

Balzer H (2015) "Will Russia Waste Another Crisis? The 2014-15 Economic Downturn and the Prospects for Russian Economic Reform", IN Putin's Third Term: Assessments amid Crisis, Washington, DC: Center on Global Interests. pp. 29-46. Available at: http://globalinterests.org/2015/03/12/putins-third-term-assessments-amid-crisis/.

Bernstein TP, Li H-Y (eds) (2010) China learns from the Soviet Union, 1949-Present. Lexington Books, Lanham, MD.

Bhattacharya, S, Shilpa (2012) "China Moving Ahead in the Global Nanotechnology Race: Evidences from Scientometric Study." Collnet J Scientometrics and Information Management 6.1: 97-117.

Block F (2011) "Innovation and the Invisible Hand of Government". In: Block, F, Matthew R. Keller(eds) State of Innovation: The U.S. Government's Role in Technology Development. Paradigm Publishers, Boulder, CO and London, p 1-26.

Bohle D, Greskovits B (2012) Capitalist diversity on Europe's periphery. Cornell University Press, Ithaca and London.

Breznitz D (2007) Innovation and the state: political choice and strategies for growth in Israel. Yale University Press, Taiwan and Ireland, New Haven and London.

Breznitz D, Murphree M (2012) Run of the Red Queen: government, innovation, globalization and economic growth in China. Yale University Press, New Haven and London.

Bychkova, O, Chernysh A, Popova E (2015) "Dirty Dances: academic-industry relations in Russia," Triple Helix Vol. 2. http://link springer.com/article/10.1186/s40604-015-0019-0 Accessed date: 21 Dec 2015.

Byrd WA, Lin Q (eds) (1990) China's rural industry : structure, development, and reform. A World Bank research publication, Oxford University Press.

Dallago B, Guglielmetti C (eds) (2011) Local economies and global competitiveness. Palgrave MacMillan, Hampshire, UK and New York.

Davies, Ken (2013) "China Investment Policy: An Update," OECD Working Papers on International Investment, $2013 / 01$.

Dawisha K (2014) Putin's Kleptocracy: who owns Russia? Simon \& Schuster, New York

Derwent World Patents Index (2014) Thomson Reuters.

Dezhina IG (2014b) "Restructuring Of The Scientific Research Institutes Formerly Subordinated To The Russian Academy Of Sciences: An Assessment Of Change". Russian Economic Developments 12(2014):36-39, Moscow.

Dezhina IG (2014a) "Technology platforms in Russia: a catalyst for connecting government, science, and business?." Triple Helix. 1.1: 1-10.

Dezhina IG, Kiseleva W (2008) Gosudarstvo, nauka i biznes v innovatsionnoi sisteme Rossii [Government, Science and Business in Russia's Innovation System]. IEPP (Institute ekonomiki perekhonnogo perioda), Moscow.

Dezhina, I G, Kiseleva W (2009) Tendentsii razvitiia nauchnykh shkol v sovremennoi Rossii (Tendencies in the development of scientific schools in contemporary Russia) Institut ekonomiki perekhodnogo perioda, Moscow.

Etzkowitz H (2008) The Triple Helix: university-industry-government innovation in action. Routledge, London.

Etzkowitz H, Leydesdorff L (2000) The dynamics of innovation: from National Systems and "Mode 2" to a Triple Helix of university-industry-government relations. Res Policy 29(2):109-123.

Florini A, Lai H, Tan Y (2012) China experiments: from local innovations to national reform. Brookings Institution Press, Washington, DC.

Fediukin I, Froumin I (2010) "Rossiiskie vyzy-flagmany (Russian higher educational institutions-leaders)" Pro et Contra 3:119-31.

Gaddy C (1996) The price of the past: russia's struggle with the legacy of a militarized economy. Brookings Institution Press, Washington, DC

Graham LR, Dezhina I (2008) Science in the new Russia: crisis, aid, reform. Indiana University Press.

Gustafson T (1980) Why doesn't Soviet science do better than it does? In: Lubrano L, Solomon S (eds) The Social Context of Soviet Science. Westview Press, Boulder, CO, pp 31-68.

Harper T (2011) Global funding of nanotechnologies \& its impact. Cientifica, London.

Heinrichs A (2006) "Putin plagiarized from Pitt professors" — Pittsburgh Tribune-Review, March 28.

Hellman J (1998) Winners take all. World Politics 50(2):203-234.

Hong S, Nong Z (2013) China's State-Owned Enterprises: Nature, Performance and Reform, Singapore and Hackensack, N.J., World Scientific.

Howell J (1993) China opens its doors: the politics of economic transition. Lynne Reiner, Boulder, CO.

Huang, C, Sharif N (2015) "Global technology leadership: The case of China". Science and Public Policy 42(No. 4) August, Advance Access Online.

Jakobson L (ed) (2007) Innovation with Chinese characteristics: high-tech research in China. Palgrave MacMillan, Hampshire, UK and New York

Jonkers K (2010) Mobility, migration and the Chinese scientific research. Routledge, System.

Josephson P (2010) Lenin's Laureate: Zhores Alferov's life in communist science. MIT Press, Cambridge, MA

Klochikhin EA (2012) Russia's innovation policy: stubborn path-dependencies and new approaches. Res Policy 41(9):1620-1630.

Kostoff RN, Stump JA, Johnson D, Murday JS, Clifford G, Lau Y, Tolles WM (2006) The structure and infrastructure of the global nanotechnology literature. J Nanoparticle Res 8(3):301-321.

Kotsemir MN (2012) Publication activity of Russian researches in leading international scientific journals. Acta Nat 4(2):14-35.

Kramer A (2014) "In Moscow, a Financial District in Name Only". The New York Times

Lardy NR (2014) Markets over Mao: the rise of private business in China. The Peterson Institute for International Economics, Washington, DC

Lewis JI (2013) Green innovation in China: China's wind power industry and the global transition to a low-carbon economy. Columbia University Press, New York.

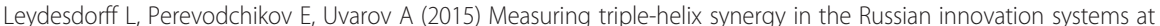
regional, provincial, and national levels. J Assoc Information Sci Technol 66(6):1229-1238. 
Li T, Shapira P, Yu M (2014) Developing an innovative materials enterprise in China: a nanotechnology small business case study. Chinese Management Studies 8(2):5-5.

Ling Z (2006) The Lenovo Affair: The Growth of China's Computer Giant and its Takeover of IBM-PC, Translated by Martha Avery. John Wiley \& Sons, Singapore.

Mazzucato M (2013) The entrepreneurial state: debunking public vs private sector myths. Athenem Press, London and New York.

Mckinsey Global Institute (2015) The China Effect on Global Innovation.

Mehta A, Herron P, Motoyama Y, Appelbaum R, Lenoir T (2012) Globalization and de-globalization in nanotechnology research: the role of China. Scientometrics 93(2):439-458.

Moscow Times (2014) Russia's Rusnano Seeks Chinese Investment in Nanotechnology, September 9. http:/www. themoscowtimes.com/business/article/russia-s-rusnano-seeks-chinese-investment-in-nanotechnology/506732.html Accessed date: 21 Dec 2015.

Motoyama Y, Cong C, Appelbaum R (2014) Observing regional divergence of Chinese nanotechnology centers. Technological Forecasting \& Social Change. No. 81, p 11-21.

Nee V, Opper S (2012) Capitalism from below: markets and institutional change in China. Harvard University Press, Cambridge, MA and London.

Nolan P (2014) Chinese firms, global firms: industrial policy in the era of globalization. Routledge, London and New York.

Organisation for Economic Co-operation and Development (2013a) Main Science and Technology Indicators. OECD. Stat

Organisation for Economic Co-operation and Development (2013b) OECD Economic Surveys: Russian Federation.

P.T (2015) "China's Diaspora Brings it Home," Nature. p 527. S68-71.

Pei M (1994) From reform to revolution: the demise of communism in China and the Soviet Union. Harvard University Press, Cambridge, MA.

Poisk. 2015.

Qi R (2015) "Russians aid China as foreign experts," China Daily, May 8 http://www.chinadaily.com.cn/world/ 2015xiattendwwii/2015-05/08/content_20663655.htm.

Rekord SI (2013) "Rol-biotkhnologicheskikh klasterov v razvitii Edinogo ekonomicheskogo prostranstva Rossii, Belorussii i Kazakhstana, (The role of biotechnology clusters in the development of the Single Economic Space of Russia, Belarus and Kazakhstan)". Evraziiskaia integratsiia: ekonomika pravo, politika No. 13:51-55.

Rhoads RA, Wang K, Shi X, Chang Y (2014) China's rising research universities: a new era of ambition. Johns Hopkins University Press, Baltimore.

Rochlitz M, Kulpina V, Remington T, Yakovlev A (2015) "Performance incentives and economic growth: regional officials in Russia and China". Eurasian Geography and Economics. Online.

Roffey R (2010) Biotechnology in Russia: why is it not a success story? FOl: Swedish Defence Research Agency, User Report FOI-R-2986-SE, Stockholm, www.foi.se Accessed date: 21 Dec 2015.

Sachs, J, Woo WT (1994) "Reform in China and Russia". Economic Policy. p 101-145.

Sagieva G (2011) "Biotechnology: national policy and development priorities in Russia,". In: Göransson B, Pålsson CM (eds) Biotechnology and Innovation Systems: The Role of Public Policy. Edward Elgar, Cheltenham, UK and Northhampton, MA, pp 333-364.

Segal A (2003) Digital dragon: high-technology enterprises in China. Cornell University Press, New York.

Simachev I, Kuzyk M, Friginna V (2014) "Vzaimodeistvie rossiiskikh kompanii i issledovaetlskikh organizatysii v provedenil NIOKR: tretii ne lishnii? (Cooperation between Russian Companies and Research Organizations in organizing and conducting R\&D: Is the Third Spiral Superfluous?". Vopr Ekon No. 7:4-34.

Sobolevsky A (2014) Why Russia is falling behind in the science race: The reform of the Russian Academy of Sciences is not popular with scientists. Especially in Siberia. www.opendemocracy.net. Accessed date: 21 Dec 2015.

Strategy\& (2014) China's innovation is going global: 2014 China innovation survey. PWC.

Sun Y, von Zedtwitz M, Simon DF (eds) (2008) Global R\&D in China. Routledge, London and New York.

Suttmeier, RP, Cong C, DF Simon (2006) China's Innovation Challenge and the Remaking of the Chinese Academy of Sciences. Innovations, p 78-97.

Teets J (2014) Civil society under authoritarianism: the China model. Camabridge University Press, New York.

Thomson Reuters (2013) Web of Science.

Vogel EF (1989) One step ahead in China: Guangdong under reform. Harvard University Press, Cambridge, MA and London.

Walsh KA (2014) China's emerging defense innovation system: making the wheels turn. In: Cheung TM (ed) Forging China's Military Might: A New Framework for Assessing Innovation. John's Hopkins University Press, Baltimore, pp 109-135.

Wang X, Xu S, L D, Liang Y (2012) The role of Chinese-American scientists in China-US scientific collaboration: a study in nanotechnology. Scientometrics 91:737-749.

Wedeman A (2012) Double Paradox: Rapid Growth and Rising Corruption in China, Ithaca and London: Cornell University Press.

Westerlund F (2011) Russian Nanotechnology R\&D: thinking big about small scale science. FOI Swedish Defense Research Agency, Stockholm.

World Economic Forum (2015) Global Competitiveness Reports.

World Intellectual Property Organisation (2011) Statistics Database.

Xue L (1997) "A historical perspective on China's innovation system reform: a case study.". J Eng Technol Manag 14.2:67-81.

Zheng, Y, Tong SY (2014) "Introduction." In: Y Zheng and SY Tong (eds) China's Evolving Industrial Policies and Economic Restructuring. Routledge, p 1-14.Zhdanov A (2013) "Russian scientist on working in China: research independence and financial security", Russia Beyond the Headlines, Asia June 12 http://rbth.asia/sciencentech/ 2013/06/12/russian_scientist_on_working_in_china_research_independence_and_47299.html. 
Zhou KX (1996) How the farmers changed china: power of the people. Westview Press, Boulder, CO.

Zhou Y (2008) The inside story of China's high-tech industry: making silicon valley in Beijing. Roman and Littlefield, Latham, MD

Zhou C (2012) "From a university-run enterprise to a leading group of regional IT industrial clusters: in a perspective of an academia government industry triple helix." In: C Petti (ed) Technological Entrepreneurship in China: How Does it Work? Edward Elgar, p 66-85

Zhou P, Leydesdorff $L$ (2006) The emergence of China as a leading nation in science. Res Policy 35(1):83-104

Zweig D (2009) Returnees, Diasporas and Failure: Can governments benefit from skilled outmigration? SSRC Migration \& Development Conference Paper No. 5.

Zweig D (2002) Internationalizing China. Cornell University Press, New York

Zweig D, Chung SF, Vanhonacker W (2006) "Rewards of technology: Explaining China's reverse migration", Journal of International Migration and Integration 7(4):449-71.

Submit your manuscript to a SpringerOpen ${ }^{\circ}$ journal and benefit from:

- Convenient online submission

- Rigorous peer review

- Immediate publication on acceptance

- Open access: articles freely available online

- High visibility within the field

- Retaining the copyright to your article

Submit your next manuscript at $>$ springeropen.com 